\title{
Chilocorus renipustulatus (Coleoptera: Coccinellidae) dominates predatory ladybird assemblages on Sorbus aucuparia (Rosales: Rosaceae)
}

\author{
EMANUEL KULA ${ }^{1}$ and OLDŘICH NEDVĚD ${ }^{2,3}$ \\ ${ }^{1}$ Faculty of Forestry and Wood Technology, Mendel University in Brno, Zemědělská 3, 61300 Brno, Czech Republic; \\ e-mail:kula@mendelu.cz \\ ${ }^{2}$ Faculty of Science, University of South Bohemia, and ${ }^{3}$ Institute of Entomology, Biology Center, Academy of Sciences \\ of the Czech Republic, Branišovská 31, 37005 České Budějovice, Czech Republic; e-mail: nedved@prf.jcu.cz
}

Key words. Coccinellidae, Chilocorus renipustulatus, scale insect, mountain ash, Sorbus aucuparia, abundance, phenology, melanism

\begin{abstract}
Fourteen predatory species of ladybirds (Coleoptera: Coccinellidae) were collected from May to October 2008 from mountain ash (Sorbus aucuparia) infested with the scale insect Chionaspis salicis at 31 localities in the Ore Mountains, northern Bohemia, Czech Republic. Chilocorus renipustulatus, usually a rare species, made up $85 \%$ of the individuals collected (1690). Other abundant species were Coccinella septempunctata, Calvia quatuordecimguttata, Adalia bipunctata and Adalia decempunctata. The invasive alien Harmonia axyridis was present but made up less than one per cent of the individuals collected. Niche overlap between pairs of ladybird species measured in terms of the coefficient of community, Morisita's index and cluster analysis showed that microhabitat preferences were similar and hence the possibility of competition was high in two pairs of congeneric species (Chilocorus and Calvia). Larvae of Ch. renipustulatus were abundant from mid-June through August and were still present in October.
\end{abstract}

\section{INTRODUCTION}

Mountain ash (Sorbus aucuparia Linnaeus) has become an important substitute woody plant in stands growing in seriously air-polluted locations at higher elevations of the Krušné hory Mts (Ore Mountains) at the north-western border of the Czech Republic (Balcar et al., 2008). This tree species is relatively resistant to sulphur dioxide, grows fast and forms a local environment with leaf litter improving soil conditions (Kubelka, 1993, Ulbrichová \& Podrázský, 2002). The attractiveness of this woody plant for forest animals (browsing, deer de-barking) is a disadvantage for the plant itself (Sloup, 2008). The weakened trees are exposed to subsequent attack by insect pests and fungal pathogens (Kula et al., 2009).

Important leaf chewing pests of mountain ash include weevils (Urban, 1999, Kula \& Šimon, 2007). Further, heavy defoliation of mountain ash is caused by the chrysomelid Gonioctena (Goniomena) quinquepunctata (Fabr.) (Urban, 1998, Kula, 1999). In addition, caterpillars of 84 species of Lepidoptera have been obtained from mountain ash (Kula et al., 2009). Important sap sucking insects on mountain ash in Central Europe include the scale insects Diaspidiotus ostreaeformis (Curtis), Diaspidiotus perniciosus (Comstock), Diaspidiotus pyri (Lichtenstein), Lepidosaphes ulmi (L.), Parlatoria oleae (Colvée) and Pseudaulacaspis pentagona (Targioni Tozzetti) (Watson, 2005). Chionaspis salicis (Linnaeus) was reported from mountain ash in Germany (Lemme, 2010).

Potentially detrimental hemipterans and some chrysomelid eggs and larvae are preyed upon by several species of ladybird beetles. This paper presents the results of a survey of beneficial predatory ladybird beetles on mountain ash in the stressful conditions of the Ore Mountains. We discuss their species composition, abundance, phenology and niche overlap. Among these species, prevalence of coccidophagous ladybirds was expected due to infestation of the observed trees by scale insects, which was demonstrated by the unusual dominance of the relatively rare ladybird Chilocorus renipustulatus (Scriba).

\section{MATERIAL AND METHODS}

The study area was situated in northern Bohemia, in the Czech Republic. The area included 31 localities situated in the "Děčínská vrchovina" Uplands $\left(50^{\circ} 47^{\prime} \mathrm{N}, 14^{\circ} 07^{\prime} \mathrm{E}-\right.$ localities $1-3)$ and the eastern part of the Ore Mountains to Mount St. Sebastian $\left(50^{\circ} 30^{\prime} \mathrm{N}, 13^{\circ} 16^{\prime} \mathrm{E}-\right.$ localities 4-31; Table 1, Fig. 1). Altitudes sampled ranged from about 500 to 900 meters a.s.1. Seven samples were collected, two in May and five at monthly intervals from 14 June to 15 October 2008 (Table 2). Mountain ash (S. aucuparia) aged 15-60 years infested with Ch. salicis was studied at each locality. To obtain a representative sample, ladybirds were collected from five different trees on each occasion. At the time of the first sample (7 May 2008), the phenological stage of the trees differed among the localities, from stands with unfolded leaves to fully expanded leaves.

The insects were sampled by shaking them from the crowns of the trees by means of $4 \mathrm{~kg}$ heavy hammer blows to the trunks of the trees. Two pieces of canvas, each $2 \times 2 \mathrm{~m}$ in size, were placed on the ground under the crowns of the trees to catch the insects. Samples from the five trees were pooled. The insects, including immature individuals, were killed and preserved in $75 \%$ ethanol. Larvae were identified using the field key of Savoiskaya \& Klausnitzer (1973). Eggs of ladybird beetles are tightly attached to the substrate and cannot be sampled by beating. Pupae can be sampled with only limited efficiency. 
TABLE 1. Localities at which the mountain ash Sorbus aucuparia was sampled. Altitude, coordinates, grid-map square number, total abundance of predatory ladybirds and of Chilocorus renipustulatus (in parentheses) are presented.

\begin{tabular}{|c|c|c|c|c|c|c|}
\hline No. & Settlement & $\mathrm{m}$ & $\mathrm{N}$ & $\mathrm{E}$ & Square & Individuals \\
\hline 1 & Sněžník & 713 & $50^{\circ} 47^{\prime} 40^{\prime \prime}$ & $14^{\circ} 05^{\prime} 55^{\prime \prime}$ & 5150 & $30(17)$ \\
\hline 2 & Sněžník & 598 & $50^{\circ} 47^{\prime} 03^{\prime \prime}$ & $14^{\circ} 05^{\prime} 17^{\prime \prime}$ & 5150 & $69(58)$ \\
\hline 3 & Rájec & 526 & $50^{\circ} 47^{\prime} 59^{\prime \prime}$ & $14^{\circ} 01^{\prime} 10^{\prime \prime}$ & 5250 & $22(7)$ \\
\hline 4 & Krásný les & 672 & $50^{\circ} 45^{\prime} 38^{\prime \prime}$ & $13^{\circ} 58^{\prime} 28^{\prime \prime}$ & 5250 & $74(70)$ \\
\hline 5 & Krásný les & 734 & $50^{\circ} 45^{\prime} 05^{\prime \prime}$ & $13^{\circ} 57^{\prime} 16^{\prime \prime}$ & 5250 & $34(27)$ \\
\hline 6 & Adolfov & 703 & $50^{\circ} 45^{\prime} 11^{\prime \prime}$ & $13^{\circ} 54^{\prime} 51^{\prime \prime}$ & 5249 & $19(12)$ \\
\hline 7 & Adolfov & 756 & $50^{\circ} 44^{\prime} 02^{\prime \prime}$ & $13^{\circ} 54^{\prime} 21^{\prime \prime}$ & 5249 & $228(217)$ \\
\hline 8 & Fojtovice & 762 & $50^{\circ} 42^{\prime} 32^{\prime \prime}$ & $13^{\circ} 51^{\prime} 04^{\prime \prime}$ & 5249 & $99(94)$ \\
\hline 9 & Fojtovice & 770 & $50^{\circ} 43^{\prime} 16^{\prime \prime}$ & $13^{\circ} 49^{\prime} 56^{\prime \prime}$ & 5249 & $26(15)$ \\
\hline 10 & Cínovec & 868 & $50^{\circ} 43^{\prime} 36^{\prime \prime}$ & $13^{\circ} 45^{\prime} 44^{\prime \prime}$ & 5248 & $22(13)$ \\
\hline 11 & Nové Město & 832 & $50^{\circ} 41^{\prime} 51^{\prime \prime}$ & $13^{\circ} 43^{\prime} 20^{\prime \prime}$ & 5348 & $15(13)$ \\
\hline 12 & Nové Město & 862 & $50^{\circ} 42^{\prime} 16^{\prime \prime}$ & $13^{\circ} 41^{\prime} 31^{\prime \prime}$ & 5348 & $47(44)$ \\
\hline 13 & Fláje & 782 & $50^{\circ} 41^{\prime} 49^{\prime \prime}$ & $13^{\circ} 37^{\prime} 03^{\prime \prime}$ & 5347 & $59(51)$ \\
\hline 14 & Fláje & 664 & $50^{\circ} 41^{\prime} 45^{\prime \prime}$ & $13^{\circ} 34^{\prime} 03^{\prime \prime}$ & 5347 & $36(32)$ \\
\hline 15 & Dlouhá louka & 800 & $50^{\circ} 41^{\prime} 31^{\prime \prime}$ & $13^{\circ} 38^{\prime} 32^{\prime \prime}$ & 5347 & $53(46)$ \\
\hline 16 & Dlouhá louka & 863 & $50^{\circ} 39^{\prime} 17^{\prime \prime}$ & $13^{\circ} 38^{\prime} 37^{\prime \prime}$ & 5347 & $114(107)$ \\
\hline 17 & Buttersteig & 742 & $50^{\circ} 38^{\prime} 08^{\prime \prime}$ & $13^{\circ} 36^{\prime} 54^{\prime \prime}$ & 5347 & $44(34)$ \\
\hline 18 & Litvínov & 496 & $50^{\circ} 37^{\prime} 05^{\prime \prime}$ & $13^{\circ} 37^{\prime} 19^{\prime \prime}$ & 5446 & $25(1)$ \\
\hline 19 & Boleboř & 855 & $50^{\circ} 33^{\prime} 18^{\prime \prime}$ & $13^{\circ} 23^{\prime} 03^{\prime \prime}$ & 5446 & $59(50)$ \\
\hline 20 & Boleboř & 810 & $50^{\circ} 32^{\prime} 59^{\prime \prime}$ & $13^{\circ} 23^{\prime} 16^{\prime \prime}$ & 5446 & $39(23)$ \\
\hline 21 & Boleboř & 722 & $50^{\circ} 32^{\prime} 40^{\prime \prime}$ & $13^{\circ} 23^{\prime} 51^{\prime \prime}$ & 5446 & $42(38)$ \\
\hline 22 & Jedlák & 870 & $50^{\circ} 34^{\prime} 50^{\prime \prime}$ & $13^{\circ} 25^{\prime} 33^{\prime \prime}$ & 5446 & $68(60)$ \\
\hline 23 & Malý háj & 821 & $50^{\circ} 34^{\prime} 54^{\prime \prime}$ & $13^{\circ} 24^{\prime} 47^{\prime \prime}$ & 5446 & $17(16)$ \\
\hline 24 & Svahová & 800 & $50^{\circ} 33^{\prime} 35^{\prime \prime}$ & $13^{\circ} 24^{\prime} 25^{\prime \prime}$ & 5446 & $68(49)$ \\
\hline 25 & Svahová & 798 & $50^{\circ} 33^{\prime} 01^{\prime \prime}$ & $13^{\circ} 24^{\prime} 07^{\prime \prime}$ & 5446 & $21(12)$ \\
\hline 26 & Orasín & 562 & $50^{\circ} 31^{\prime} 58^{\prime \prime}$ & $13^{\circ} 23^{\prime} 44^{\prime \prime}$ & 5446 & $90(80)$ \\
\hline 27 & Mezihoří & 686 & $50^{\circ} 32^{\prime} 05^{\prime \prime}$ & $13^{\circ} 21^{\prime} 44^{\prime \prime}$ & 5446 & $96(87)$ \\
\hline 28 & Kálek & 714 & $50^{\circ} 34^{\prime} 40^{\prime \prime}$ & $13^{\circ} 18^{\prime} 12^{\prime \prime}$ & 5445 & $48(45)$ \\
\hline 29 & Hora sv. Šebestiána & 842 & $50^{\circ} 31^{\prime} 28^{\prime \prime}$ & $13^{\circ} 14^{\prime} 09^{\prime \prime}$ & 5445 & $79(78)$ \\
\hline 30 & Hora sv. Šebestiána & 837 & $50^{\circ} 30^{\prime} 41^{\prime \prime}$ & $13^{\circ} 16^{\prime} 21^{\prime \prime}$ & 5445 & $36(28)$ \\
\hline 31 & Celná-Místo & 745 & $50^{\circ} 28^{\prime} 38^{\prime \prime}$ & $13^{\circ} 16^{\prime} 35^{\prime \prime}$ & 5545 & $18(13)$ \\
\hline
\end{tabular}

The number of individuals of each species in each sample (for a particular locality and day) was expressed in terms of the relative proportion $\left(\mathrm{p}_{\mathrm{i}}\right)$ of the total catch for the entire year, independent of the other species $\left(\Sigma \mathrm{p}_{\mathrm{i}}=1\right.$ for each species $)$. Niche overlap was then determined using the coefficient of community $\left[\mathrm{S} 1=\Sigma \min \left(\mathrm{p}_{\mathrm{i}}, \mathrm{q}_{\mathrm{i}}\right)\right]$ and Morisita's index $\left[\mathrm{S} 2=2 \Sigma\left(\mathrm{p}_{\mathrm{i}} \bullet \mathrm{q}_{\mathrm{i}}\right) /\left(\Sigma \mathrm{p}_{\mathrm{i}}^{2}\right.\right.$ $\left.\left.+\Sigma \mathrm{q}^{2}\right)\right]$. The Weighted pair-group average method after applying 1-Pearson $r$ measure of similarity was used for cluster analysis.

\section{RESULTS}

Altogether 1690 individuals of 14 predatory species of ladybirds (Table 2), including adults, pupae and larvae were collected. The single species Chilocorus renipustulatus made up $85 \%$ of all individuals. The second most abundant species was Coccinella septempunctata Linnaeus (4\%), the next Calvia quatuordecimguttata (Linnaeus) (3\%) and two more species, Adalia bipunctata (Linnaeus) and $A$. decempunctata (Linnaeus), each made up over $1 \%$. The mycophagous ladybird Halyzia sedecimguttata (Linnaeus) (7 individuals) was not included in the results and analyses. The abundance of $\mathrm{Ch}$. renipustulatus differed among the localities, ranging from 1 to 217 individuals over the entire season, with a median of 38 and mean of 46 individuals per site. Abundance was not correlated with the geographical position of a particular locality (that is: there was no north-south or west-east gradient), or with the altitude of the sites.

The seasonal trend in abundance of Ch. renipustulatus was biphasic, with a ten-fold increase between mid-June and early July, due to a massive emergence of larvae of the new generation, and with adult emergence in August to September (Table 2, Fig. 2). All the other species together showed a more gradual change in abundance with a minimum in late May and maximum in early September. The highest increase was between July and August, when many aphidophagous ladybirds enter diapause.

The first larvae of Ch. renipustulatus were collected in mid June ( $43 \%$ of the individuals collected), and were most abundant in early July, when $96 \%$ of the population comprised immature individuals. Larvae occurred at most localities. The first pupae were recorded in early July and were most common in early August, when $52 \%$ of the population were immature individuals. The number of larvae and pupae decreased in September $(10 \%)$, but a few individuals $(1 \%)$ were still present in early October.

Calvia quatuordecimguttata also reproduced on these trees as larvae were present in June (Table 2). A few larvae of Calvia decemguttata (Linnaeus) were found in June and July and a single larva of Aphidecta obliterata 


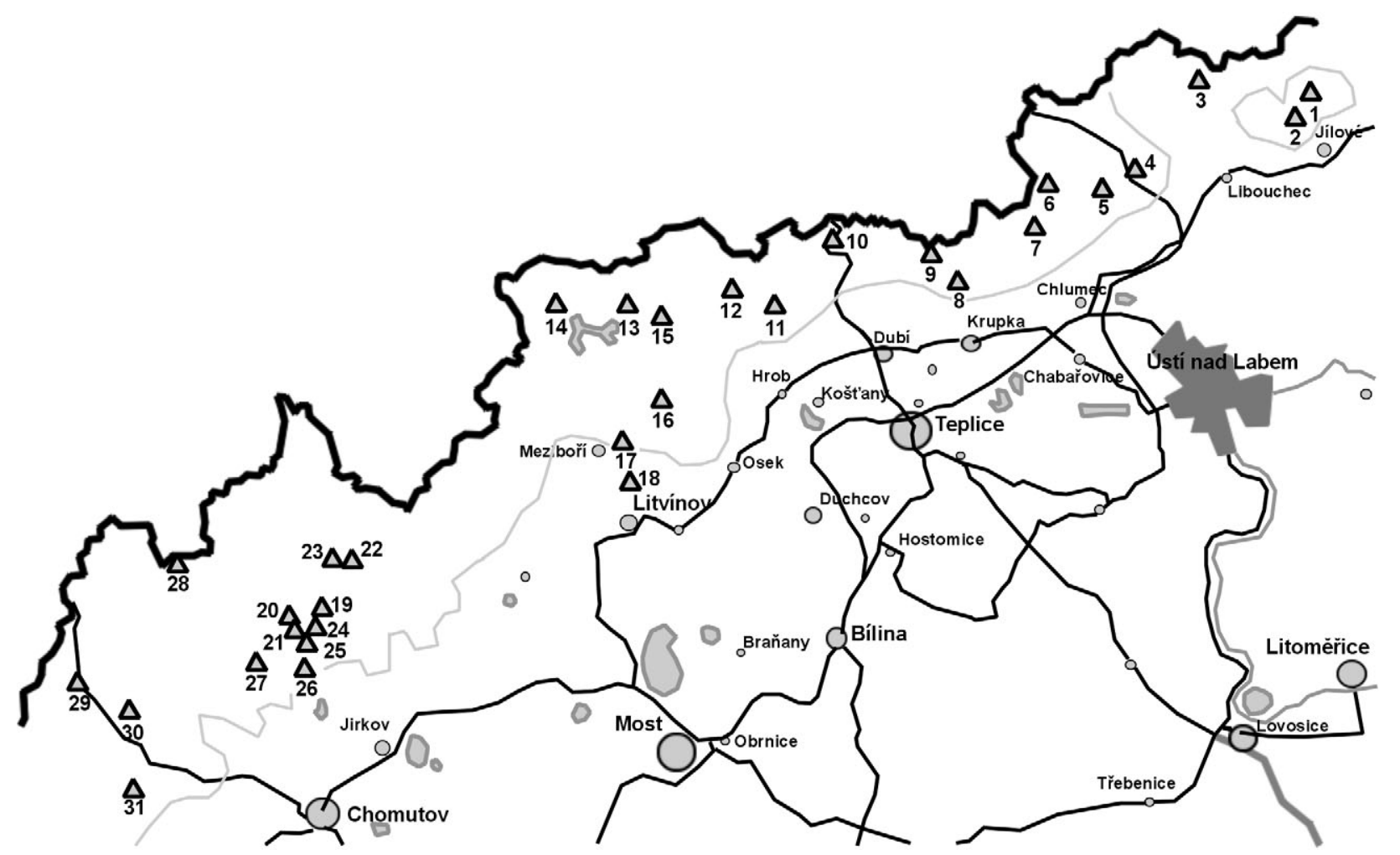

Fig. 1. Geographical distribution of the 31 localities studied in the north western part of the Czech Republic.

(Linnaeus) in July. Three larvae of Harmonia axyridis (Pallas) were recorded in June and October. The other species were not found reproducing on these trees.

All individuals of $A$. obliterata belonged to the pale morph and either had or lacked semilunar black markings on their elytra. Of the Adalia bipunctata, 24 were the typical pale morph, four the four-spotted melanic morph (quadrimaculata) and one the six-spotted melanic morph (sexpustulata). Of the $A$. decempunctata, six were the typical pale morph, 12 the chequered form (decempustulata) and five melanic (bimaculata). All the individuals of $H$. axyridis were the pale spotted succinea morph.
Niche overlap between pairs of ladybird species based on the coefficient of community ranged from 0 to 0.288 and on Morisita's index from 0 to 0.320 . These values group together those species that tend to occur simultaneously. The following pairs of species had values of both indices over 0.20: Coccinella septempunctata and Adalia bipunctata; Calvia quatuordecimguttata and $C$. decemguttata; C. septempunctata and C. quatuordecimguttata; A. decempunctata and Anatis ocellata (Linnaeus). Cluster analysis indicated similar groupings (Fig. 3) with the addition of Ch. renipustulatus and Ch. bipustulatus (Linnaeus).

TABLE 2. Number of individuals of all developmental stages (and number of immature individuals in parentheses) of fourteen ladybird species sampled on seven sampling days during the course of a season.

\begin{tabular}{lcccccccc}
\hline & $07-05$ & $26-05$ & $15-06$ & $05-07$ & $05-08$ & $05-09$ & $09-10$ & Total \\
\hline Exochomus quadripustulatus & 1 & 0 & 0 & 0 & 0 & 0 & 0 & 1 \\
Chilocorus renipustulatus & 25 & 20 & $44(18)$ & $392(376)$ & $299(170)$ & $334(35)$ & $323(3)$ & $1437(602)$ \\
Chilocorus bipustulatus & 0 & 0 & 2 & 2 & 1 & 7 & 3 & 15 \\
Calvia quatuordecimguttata & 6 & 0 & $15(11)$ & 4 & 9 & 11 & 9 & $54(11)$ \\
Calvia decemguttata & 0 & 0 & $2(1)$ & $3(3)$ & 1 & 3 & 2 & $11(4)$ \\
Propylea quatuordecimpunctata & 0 & 1 & 0 & 1 & 1 & 0 & 0 & 3 \\
Coccinella septempunctata & 5 & 1 & 0 & 8 & 18 & 26 & 11 & 69 \\
Adalia bipunctata & 0 & 0 & 0 & 4 & 5 & 15 & 5 & 29 \\
Adalia decempunctata & 1 & 0 & 0 & 8 & 8 & 4 & 2 & 23 \\
Harmonia axyridis & 0 & 1 & $2(2)$ & 1 & 7 & 2 & $3(1)$ & $16(3)$ \\
Anatis ocellata & 1 & 0 & 0 & 0 & 3 & 7 & 2 & 13 \\
Aphidecta obliterata & 3 & 0 & 0 & $2(1)$ & 2 & 2 & 2 & $11(1)$ \\
Hippodamia septemmaculata & 1 & 0 & 0 & 0 & 0 & 0 & 0 & 1 \\
Hippodamia variegata & 0 & 0 & 0 & 0 & 7 & 0 & 0 & 7 \\
\hline Total & 43 & 23 & $65(32)$ & $425(380)$ & $361(170)$ & $411(35)$ & $362(4)$ & $1690(621)$ \\
\hline
\end{tabular}




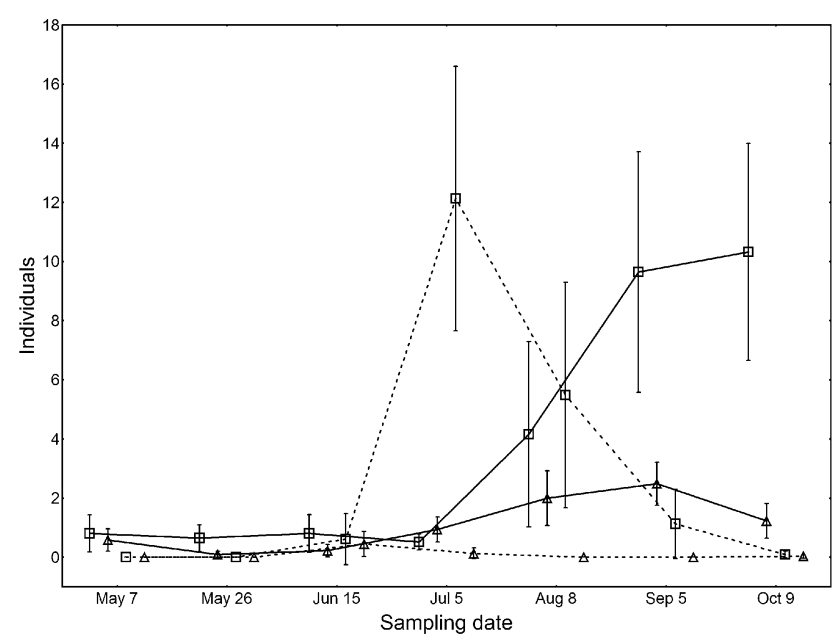

Fig. 2. Seasonal population dynamics of predatory ladybirds on mountain ash in 2008. Squares - Chilocorus renipustulatus; triangles - other species pooled; dashed lines - larvae and pupae; solid lines - adults. Plotted are means per sampling site $\pm 95 \%$ confidential intervals.

\section{DISCUSSION}

\section{Species dominance}

The dominant ladybird on most sites in the study area with mountain ash Sorbus aucuparia was the coccidophagous Chilocorus renipustulatus, which is rarely common. In a previous survey over a period of four years in the Czech Republic (Nedvěd, 1989), only two individuals of this species were encountered in 5,222 ladybirds collected. In a long term survey over 25 years on several tree species (unpublished data) we found 34 individuals of Ch. renipustulatus among 14,435 coccinellids. This species was not found at all in several other surveys made in orchards in Europe, including the Czech Republic (Hodek \& Honěk, 1996). In orchards in the Leningrad (= St. Petersburg) region it was the seventh most common species, after Adalia bipunctata, Coccinella septempunctata, Calvia quatuordecimguttata, C. quinquepunctata Linnaeus, Propylea quatuordecimpunctata (Linnaeus) and A. decempunctata, with a few species less common (Semyanov, 1996) and formed 2.7\% of all ladybird individuals (Semjanov 1965). Klausnitzer (1994) classified Ch. renipustulatus as frequent and widespread in Thuringia (Germany). It is likely that Ch. renipustulatus is often common on ash, but nobody, hereto, has studied ladybirds on mountain ash intensively. Simple visual observations during other years, however, did not record conspicuously high abundances of Ch. renipustulatus.

\section{Prey relations}

The abundance and dominance of Ch. renipustulatus recorded in this study was associated with abundance of its prey, the scale insect, Chionaspis salicis. It was not possible, however, to quantify the abundance of the prey species because it lives high in the crowns of the trees and the individuals cannot be collected by shaking the trees. We estimated by visual observation that the infestation of trees in 2008 was not exceptionally high. Ch. renipustu-

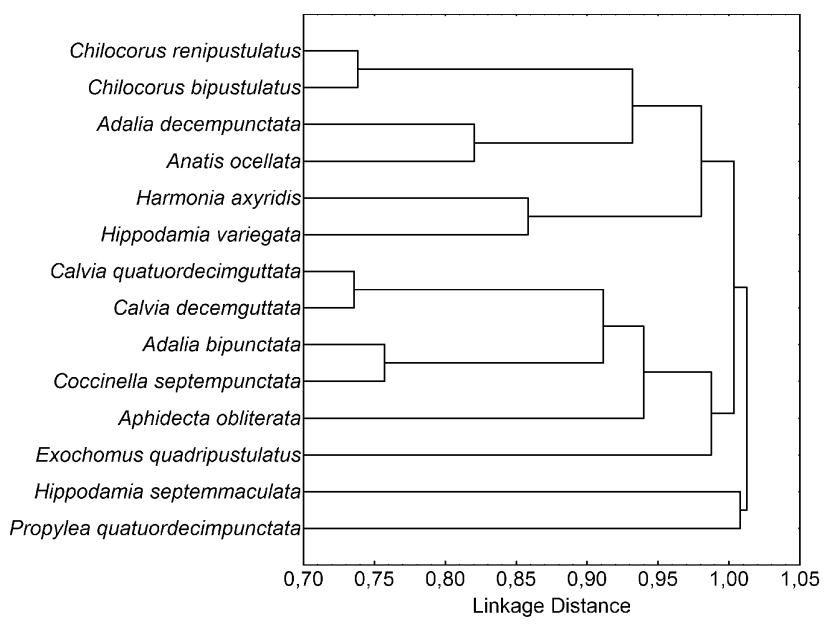

Fig. 3. Clustering of the ladybird species based on the weighted pair-group average method after applying 1-Pearson $r$ measure of similarity of relative proportions of individuals $\left(\mathrm{p}_{\mathrm{i}}\right.$, $\mathrm{q}_{\mathrm{i}}$ ) in each sample. Note the small groups (pairs of species) joined at short linkage distances: the main branching on the right of the graph has little importance.

latus has also been reported feeding on Ch. salicis on $S$. aucuparia in Germany (Lemme, 2010). In Britain, Ch. renipustulatus is recorded feeding on coccids on willows (Salix). Ch. renipustulatus is also associated with Unaspis euonymi (Comstock), on spindle (Euonymus spp.) (Kirby, 2005, 2008).

There are several other ladybird beetles that specialize on scale insects in central Europe, such as the congeneric Ch. bipustulatus that was less abundant in our samples. In southern Europe, the Mediterranean and the Middle East, $C h$. renipustulatus is replaced by other congeneric species, namely Ch. bipustulatus (Rodas et al., 2006). Populations of the scale Quadraspidiotus perniciosus (Comstock) in apple and peach orchards are controlled by both Ch. renipustulatus and Ch. bipustulatus in Romania (Trandafirescu et al., 2004). Both species also prey upon Pseudaulacaspis pentagona (Targioni Tozzetti) in Serbia (Graora \& Spasić, 2008), the newly introduced Japanese wax scale Ceroplastes japonicus Green, a pest of laurel in Croatia (Milek \& Simala, 2008), the California scale Q. perniciosus in fruit-growing areas of Dagestan, Russia (Gamzaev, 2002) and the Dictyospermum scale Chrysomphalus dictyospermi (Morgan) in citrus groves in Georgia (Chkhaidze \& Yasnosh, 2001).

Aphids were rare on the mountain ash trees studied, and larval development of most of the ladybird species recorded on these trees was not observed. Both species of Calvia might have fed on psyllids, the generalist $H$. axyridis on psyllids, coccids, or non-prey food groups such as fruit, fungi and pollen (Berkvens et al., 2010).

\section{Phenology}

Ch. renipustulatus probably only completed one generation during the entire season, but the reproductive period extended into late summer and autumn, which is unusual in comparison with other ladybirds in central Europe (Hodek, 1996). Only the invasive H. axyridis is 
known to produce progeny (second or third generation) regularly in October (Adriaens et al., 2008). In Britain, the earliest record of a newly emerged adult of $C h$. renipustulatus is June 18th, which is later than other coccinellids. Mating between males and females of the old and new generation has been observed (Majerus, 1994). In the Maikop district (Adygeya, southern Russia), Ch. renipustulatus has two generations a year, compared with one in St. Petersburg (northern Russia) (Pantyukhov, 1968). None of the ladybird species recorded here was present solely in the autumn but $C$. septempunctata and $A$. bipunctata reached highest numbers in September and thus are suggested as likely overwintering migrants.

\section{Niche overlap}

The cluster analysis and niche overlap indices indicated that several pairs of species of ladybirds usually occurred together, which might indicate that they have similar microhabitat preference. Although it can be argued that congeneric species simply share aspects of their biology by common descent, conversely it may be hypothesized that closely related, sympatric species may diverge, as a part of a speciation process, to avoid competition or interbreeding. Interestingly, two pairs of congeneric species (Chilocorus and Calvia) clustered closely together. This co-occurrence suggests that interspecific competition has not structured particular ladybird assemblages (that is: related species did not substantially diverge) (Machac et al., 2011). On the other side, two Adalia species, (the most closely related of the congeners here) did not cluster together. The two Hippodamia species were too rare to show clear relationships. Niche overlap between the two Chilocorus species and the other ladybirds (Table 3) was overestimated, because the former occur mainly on the branches and trunk and the latter on the leaves, but they were sampled together. A previous cluster analysis of 22 species of ladybirds occurring on a wide diversity of plants over a wide area (Nedvěd, 1999) also included pairs of congeneric species (Adalia, Scymnus). Chilocorus was not recorded in that study, but the two species of Calvia clustered close to each other (together with Oenopia conglobata (Linnaeus)).

The invasive alien Harmonia axyridis overlapped only slightly with the other ladybirds in our study. It was first recognized in the Czech Republic in 2006 (Brown et al., 2008) but has not yet become an important threat to the biodiversity of beneficial predators on mountain ash.

ACKNOWLEDGEMENTS. E.K. was funded by the grant project VZ MSM 6215648902 from the Ministry of Education of the Czech Republic and O.N. was funded by grants number QH82047 from the Ministry of Agriculture and 6007665801 from the Ministry of Education of the Czech Republic.

\section{REFERENCES}

Adriaens T., Gomez G.M.Y. \& Maes D. 2008: Invasion history, habitat preferences and phenology of the invasive ladybird Harmonia axyridis in Belgium. BioControl 53: 69-88.

Balcar V., Kula E., Lomský B., Mauer O. \& Šrámek V. 2008: Substitute tree species stands at risk due to biotic and abiotic factors. In Slodičák M., Balcar V., Novák J. \& Šrámek V.:
Lesnické hospodarení v Krušných horách. [Forestry Management in the Krušné Hory Mts.] Lesy České republiky, Grantová služba LČR, Hradec Králové, Teplice, pp. 143-178 [in Czech].

Berkvens N., Landuyt C., Deforce K., Berkvens D., Tirry L. \& De Clerce P. 2010: Alternative foods for the multicoloured Asian lady beetle Harmonia axyridis (Coleoptera: Coccinellidae). Eur. J. Entomol. 107: 189-195.

Brown P.M.J., Adriaens T., Bathon H., Cuppen J., Goldarazena A., Hagg T., Kenis M., Klausnitzer B.E.M., KováR̆ I., Loomans A.J.M., Majerus M.E.N., Nedvěd O. \& Pedersen J. 2008: Harmonia axyridis in Europe: spread and distribution of a non-native coccinellid. BioControl 53: 5-21.

Chrhaidze L. \& Yasnosh V. 2001: The Dictyospermum scale Chrysomphalus dictyospermi (Morgan) (Coccinea: Diaspididae), pest of fruit and ornamental plants in the Black Sea coast of Georgia: a review. Boll. Zool. Agr. Bachicolt. 33: 495-499.

Gamzaev I.M. 2002: Natural enemies of the California scale. Zashch. Karant. Rast. 1: 27-28 [in Russian].

Graora D. \& Spasić R. 2008: Natural enemies of Pseudaulacaspis pentagona Targioni-Tozzetti in Serbia. Pestic. Fitomed. 23: 11-16 [in Serbian]

Hodek I. 1996: Dormancy. In Hodek I. \& Honěk A. (eds): Ecology of Coccinellidae. Kluwer, Dordrecht, pp. 239-318.

Hodek I. \& HonĚK A. 1996: Ecology of Coccinellidae. Kluwer, Dordrecht, $464 \mathrm{pp}$.

KIRBY M. 2005: Kidney-spot ladybirds and scale insects. White Admiral 62: 12

KIRBY M. 2008: The ladybird, the scale and the spindle - a highly specialised relationship. British Wildlife 19: 193-196.

Klausnitzer B. 1994: Checklist der Marienkäfer (Coleoptera, Coccinellidae) Thüringens. Checklisten Thüringer Insekten 2: $13-15$.

Kubelka L. (ed.) 1993: Forest Regeneration in the Heavily Polluted NE "Krušné Hory” Mountains. Ministry of Agriculture of the Czech Republic, Prague, 133 pp. [in Czech].

Kula E. 1999: Biotic harmful agents in stands of substitute tree species. In: Proceedings of Conference "Problematika zachováni náhradních dřevin v imisní oblasti Krušných hor [Questions about Keeping Substitute Woody Plants in Airpolluted Areas of Ore Mountains]", Most, 18.-19.5.1999. pp. 19-26 [in Czech].

Kula E. \& Šmon V. 2007: Curculionidae in the crown fauna of forest trees in the area of Sněžník. Proceedings of Conference "Výsledky lesnického výzkumu v Krušných horách v roce 2006 [Results of Forestry Research in Ore Mountains in 2006]", Teplice, 19.04.2007. pp. 173-184 [in Czech].

Kula E., PAtočKa J. \& Šimon V. 2009: Caterpillars of Lepidoptera in crowns of mountain ash (Sorbus aucuparia L.) in the Ore Mts. Folia Oecol. 36(2): 94-107.

Lemme H. 2010: Image Number: 1220103. Version 4. May 2010. Available online at http://www.invasive.org/browse/ detail.cfm?imgnum $=1220103$

Machac A., Janda M., DunN R.R. \& SAnDers N.J. 2011: Elevational gradients in phylogenetic structure of ant assemblages reveal the interplay of biotic and abiotic constraints on diversity. Ecography 34: 364-371.

MaJerus M.E.N. 1994: Ladybirds. Harper Collins, London, 367 pp.

MileK T.M. \& Simala M. 2008: Japanese wax scale Ceroplastes japonicus (Green, 1921) (Hemiptera: Coccoidea: Cocidae) - a new pest in Croatia. Glasilo Biljne Zastite 8: 11-15 [in Croatian]. 
NedVĚD O. 1989: Selected Ecological Characteristics of Ladybirds (Coleoptera: Coccinellidae). Diploma thesis, Charles University, Prague, 63 pp. [in Czech].

NEDVĚD O. 1999: Host complexes of predaceous ladybeetles (Col., Coccinellidae). J. Appl. Entomol. 123: 73-76.

Pantyukhov G.A. 1968: On the photoperiodic reaction of Chilocorus renipustulatus Scriba (Coleoptera, Coccinellidae). Entomol. Obozr. 47: 45-50.

Rodas N.C., Petacchi R. \& Canovai R. 2006: Study of Coccinellids (Coleoptera) in olive orchards with different agricultural management in central Tuscany (Italy). Inform. Fitopatol. 56: 24-32 [in Italian].

Savoiskaya G.I. \& KLausnitzer B. 1973: Morphology and taxonomy of the larvae with keys for their identification. In: Hodek I. (ed.): Biology of Coccinellidae. Academia, Praha, pp. 36-55.

Semyanov V.P. 1965: Fauna and stational distribution of ladybirds (Coleoptera, Coccinellidae) in the Leningrad region. Entomol. Obozr. 44: 315-323 [in Russian].

Semyanov V.P. 1996: Lady beetles (Coleoptera, Coccinellidae) of Leningrad region orchards (fauna, biology and their role in pest population dynamics). Acta Hort. (ISHS) 422: 208-211.

SLoup M. 2008: Vliv zvěře na lesní ekosystémy v Krušných horách. [Effect of game on the forest ecosystems in the Krušné hory Mts.] In Slodičák M., Balcar V., Novák J. \& Šrámek V.: Lesnické hospodaření v Krušných horách. [For- estry Management in the Krušné Hory Mts.] Lesy České republiky, Grantová služba LČR, Hradec Králové, Teplice, pp. 201-223 [in Czech].

Trandafirescu M., Trandafirescu I., Gavat G. \& Spita V. 2004: Entomophagous complexes of some pests in apple and peach orchards in southeastern Romania. J. Fruit Ornam. Plant Res. 12: 253-261.

UlBRICHOVÁ I. \& PodRÁZsKÝ V. 2002: Evaluation of main broadleaved preparatory tree species from the viewpoint of restoration and protection of forest soils in the Ore Mountains. In: Slodičák M. \& Novák J. (eds): Výsledky lesnického výzkumu $v$ Krušných horách $v$ roce 2001. [Results of Forestry Research in Ore Mountains in 2001.] VÚLHM, JílovištěStrnady, pp. 21-28 [in Czech].

URBAN J. 1998: A contribution to the knowledge of a chrysomelid beetle Gonioctena (= Phytodecta) quinquepunctata F. (Chrysomelidae, Coleoptera). Acta Univ. Agricult. Silvicult. Mendel. Brun. 46: 7-23 [in Czech].

URBAN J. 1999: Strophosoma melanogrammum Forst. a pest on young beech trees and on European mountain ash in the Žd'ár region. J. Forest Sci. 45(2): 64-80.

WATSON G.W. 2005: Arthropods of Economic Importance Diaspididae of the World. Online at http://nlbif.eti.uva.nl/bis/ diaspididae.php (access on Feb. 9, 2005).

Received February 9, 2011; revised and accepted April 10, 2011 